\title{
PENERAPAN MODEL PEMBELAJARAN KOOPERATIF STUDENT TEAMS ACHIEVEMENT DIVISIONS (STAD) BERBASIS ERGONOMI UNTUK MENIGKATKAN PEMBELAJARAN BIOLOGI SISWA KELAS $X$ MIA1 DI SMA LABORATORIUM UNDIKSHA
}

\author{
Oleh \\ Nyoman Wijana ${ }^{1}$, Made Sukri ${ }^{2}$ \\ ${ }^{1}$ Staf pengajar pada Jurusan Biologi FMIPA Undiksha, Singaraja \\ ${ }^{2}$ Guru BK SMP Negeri 6 Singaraja, Singaraja \\ email: wijana_1960@yahoo.com,madesukri16@gmail.com
}

\begin{abstract}
ABSTRAK
Tujuan penelitian tindakan kelas ini adalah untuk mengetahui pengaruh penerapan model pembelajaran kooperatif tipe STAD berbasis ergonomi untuk meningkatkan hasil belajar siswa kelas X Mia1 SMA LAB Undiksha. Subyek penelitian ini adalah siswa kelas X Mia1 SMA laboratorium Undiksha sebanyak satu kelas dengan jumlah siswa sebanyak 22 siswa. Objek penelitian ini adalah model pembelajaran kooperatif tipe STAD berbasis ergonomi dan hasil belajar siswa. Jenis penelitian ini adalah penelitian tindakan kelas (PTK). Penelitian ini dilakukan dalam dua siklus yaitu siklus 1 dan siklus 2 dengan topik pembelajaran yaitu bakteria. Hasil penelitian menunjukkan (1) Penerapan model pembelajaran kooperatif tipe STAD berbasis ergonomi dapat meningkatkan hasil belajar siswa kelas X Mia1 SMA LAB Undiksha, (2) Pada siklus I ada 8 (36,36\%) siswa yang nilainya belum mencapai KKM, sedangkan $14(63,64 \%)$ siswa telah mencapai KKM. Nilai rerata pada siklus I adalah 73,79. Ketuntasan klasikalnya baru mencapai $63,64 \%$ dari $75 \%$ yang ditarget. Pada siklus II ada $2(9,09 \%)$ siswa yang masih nilainya belum mencapai KKM, sedangkan $20(90,91 \%)$ siswa telah mencapai KKM. Rerata nilai kelasnya sudah melebihi KKM yaitu sebesar 79,36. Ketuntasan klasikalnya adalah sebesar 90,91\%.
\end{abstract}

Kata Kunci: Penelitian Tindakan Kelas, STAD Berbasis Ergonomi

\begin{abstract}
The purpose of this classroom action research was to determine the effect of the application of ergonomics-based STAD type learning model to improve the learning outcomes of class X Mial students of SMA LAB Undiksha. The subjects of this study were as many as one class of X Mial high school students from Undiksha laboratory. The object of this study is ergonomics-based STAD type learning model and student learning outcomes. This type of research is classroom action research (CAR). This research was conducted in two cycles, namely cycle 1 and cycle 2 with the topic of learning, namely bacteria. The results showed (1) The application of ergonomics-based STAD type learning model can improve the learning outcomes of X Mial students of SMA LAB Undiksha, (2) In cycle I there were $8(36.36 \%)$ students whose grades had not yet reached the minimum


completeness criteria (MCC), while 14 ( 63.64\%) students have reached the MCC. The average value in cycle I was 73.79. The classical completeness has only reached $63.64 \%$ of the $75 \%$ targeted. In cycle II there were 2 (9.09\%) students whose grades had not yet reached the MCC, while $20(90.91 \%)$ students had reached the MCC. The average grade value has exceeded the MCC that is equal to 79.36. The classical completeness is $90.91 \%$

Keywords: Classroom Action Research, STAD Based on Ergonomics

\section{PENDAHULUAN}

Kurikulum K13 yang telah diberlakukan sampai saat ini, pada intinya sebagai penyempurnaan kurikulum sebelumnya, sehingga diharapkan mampu mengatasi rendahnya kualitas pendidikan (Anonimus, 2017). Dalam K13 terdapat pembaharuan paradigma dalam pembelajaran yaitu dari "teaching" menjadi "learning" atau "learning how to learn" yang berarti mengacu pada siswa belajar aktif. Dalam K13 guru ditempatkan sebagai fasilitator dan mediator yang membantu agar proses belajar siswa berjalan dengan baik.

Sampai saat ini implementasi K13 di lapangan belum menunjukan hasil yang optimal. Di SMA LAB Undiksha sebagai salah satu sekolah swasta di Singaraja,di mana sekolah tersebut masih mengalami kendala dalam proses pembelajaran, khususnya mengenai pelajaran biologi. Salah satu faktor yang dapat diidentifikasi sebagai penyebab masalah tersebut adalah adanya asumsi yang keliru dari para guru pengajar biologi yang menganggap bahwa pengetahuan dapat ditransfer secara utuh dari pikiran guru ke pikiran siswa. Dengan asumsi tersebut para guru mencoba memfokuskan pelajaran biologi pada upaya penuangan pengetahuan tentang biologi sebanyak mungkin kepada siswa. Dengan demikian metode transfer informasi(ceramah) dianggap sebagai metode yang paling efektif dalam menuangkan pengetahuan kepada siswa (Arends, 2004).

Pembelajaran biologi yang menggunakan metode ceramahakan menghasilkan beberapa kelemahan, untuk itu penggunaan metode ini perlu dikaji kembali dalam rangka peningkatan kualitas pembelajaran. Model pembelajaran kooperatif mengacu pada metode pengajaran dimana siswa bekerja bersama dalam kelompok kecil saling membantu dalam belajar. Model pembelajaran kooperatif adalah suatu pembelajaran melalui pembentukan kelompok-kelompok kecil dalam 
kelas. Slavin (1995) dan Warpala (2006) menyatakan bahwa siswa lebih mudah menemukan dan memahami konsep-konsep yang sulit jika mereka saling mendiskusikan masalah tersebut dengan temannya. Dalam pembelajaran dengan model kooperatif siswa memperoleh dua macam tanggung jawab. Pertama, semua siswa terlibat dalam mempelajari dan menyelesaikan tugas yang dibebankan. Kedua, meyakinkan bahwa semua siswa dalam kelompok mengerti dan memahami tentang tugas yang dibebankan padanya. Berdasarkan kelebihankelebihan yang dimiliki dalam model pembelajaran kooperatif ini, dicobakan untuk memecahkan masalah pembelajaran yang ada di sekolah.

Model pembelajaran kooperatif tipe STAD merupakan bagian dari belajar konstruktivis dimana siswa aktif terlebih dahulu mencari pengetahuan sesuai dengan cara berpikirnya, kemudian mendiskusikan dengan teman dalam kelompoknya maupun dengan guru. Dalam pembelajaran ini, siswa diajak untuk melakukan gerakan aktif, tidak duduk monoton di meja belajarnya, dan rasa nyaman yang ada di ruang kelas dapat diperhatikan oleh guru. Dengan demikian suasana belajar menjadi lebih nyaman, siswa tetap dalam keadaan sehat dan melatih siswa untuk menjadi lebih aktif, sehingga penerapan konsep ergonomi dalam pembelajaran dapat membantu untuk ikut serta meningkatkan hasil belajar siswa. Oleh karenanya model pembelajaran kooperatif tipe STAD dikombinasikan dengan konsep ergonomi sehingga dikenal dengan tipe STAD berbasis ergonomic (Wijana, 2008). Berdasarkan dokumentasi yang ada di sekolah, nilai mata pelajaran biologi pada semester ganjil tahun ajaran 2017/2018, masih tergolong rendah yaitu 63,4 dan belum mencapai KKM yang ditargetkan yaitu sebesar 70 . Berdasarkan hasil wawancara dengan guru pengajar biologi kelas X, dan para siswa, ada beberapa hal yang dapat diidentifikasi sebagai faktor penyebab masih rendahnya proses belajar biologi yaitu (a) masih sering terjadi kesalahan konsep pada diri siswa pada saat memberikan jawaban pada saat diskusi berlangsung, (b) siswa kurang berani bertanya apabila ada konsep-konsep yang belum dipahami, dan (c) pada saat pembelajaran berlangsung guru jarang meminta siswa untuk berdiskusi. 
Dari uraian di atas penulis mencoba untuk memecahkan masalah pembelajaran biologi dengan mengaitkan penggunaan model pembelajaran kooperatif tipe STAD dengan konsep Ergonomi, sehingga pemahaman konsep biologi siswa dapat meningkat, dan di satu sisi siswa merasa nyaman dan sehat, terlatih belajar lebih sistematis, efektif, dan efisien dalam menghadapi pelajaran (Wijana, 2008; Manuaba, 2003. Tujuan penelitian tindakan kelas ini adalah untuk mengetahui pengaruh penerapan model pembelajaran kooperatif tipe STAD berbasis ergonomi untuk meningkatkan hasil belajar siswa kelas X Mia1 SMA LAB Undiksha.

\section{METODE PENELITIAN}

Penelitian ini merupakan penelitian tindakan kelas (Classroom action research). Sebagai subyek dalam penelitian ini adalah siswa kelas X Mia1 SMA LAB Undiksha. Obyek penelitiannya yaitu model pembelajaran kooperatif tipe STAD berbasis ergonomi, dan prestasi belajar siswa. Penelitian ini terdiri dari dua siklus yaitu siklus I dan siklus II. Adapun langkah-langkah dalam masing-masing siklus dapat dijelaskan sebagai berikut.

Siklus I. Tahap Perencanaan: a) Meyiapkan alat-alat pengajaran berupa analisis materi pelajaran, satuan pelajaran, rencana pembelajaran. b) Membuat lembar kerja siswa (LKS). c) Membuat alat evaluasi. d) Membuat daftar nilai hasil evaluasi. e) Mempersiapkan alat-alat untuk melakukan percobaan atau eksperimen. Tahap Pelaksanaan: Pertemuan ke-1. Kegiatan Awal (20 menit): 1) Apersepsi. 2) Membagi kelas menjadi kelas menjadi 4 kelompok, tiap kelompok terdiri dari 5 orang siswa. 3) Memperkenalkan nama alat-alat serta topik kegiatan yang akan dilaksanakan. 4) Memberikan LKS serta permasalahan yang akan didiskusikan.

Kegiatan Inti (50 menit). 1) Siswa mengerjakan LKS non eksperimen. 2) Peneliti berkeliling mengawasi tiap kelompok sambil meluruskan kalau ada halhal yang menyimpang serta sambil melakukan observasi. 3) Setelah setiap kelompok selesai mengerjakan LKS, peneliti menyuruh wakil tiap anggota kelompok untuk menempekan hasil karyanya di papan tulis/papan panel. 4) Setiap 
kelompok secara bergiliran mengamati hasil karya kelompok lainnya di depan papan panel. 5) Setelah semua kelompok selesai mengamati hasil karya kelompok lainnya, maka siswa kembali ke temapt duduknya. 6) Masing-masing kelompok berdiskusi di dalam kelompoknya untuk membuat pertanyaan kepada kelompok lainnya. 7) Dalam diskusi antar kelompok, salah satu anggota kelompok yang bertanya, diwajibkan menggunakan etika, menyebut nama kelompok dan nama anggota kelompok tersebut untuk menjawab atas pertanyaan yang disampaikan. 8) Kelompok yang ditanya kemudian melakukan diskusi dalam kelompok. Selanjutnya siswa yang ditunjuk tadi mewakili kelompoknya memberikan jawaban atas pertanyaan yang diberikan dan disertai dengan argumentasiargumentasinya. 9) Setelah selesai diskusi antar kelompok, guru memberikan materi tambahan yang bersifat verivikatif atas jawaban yang diberikan siswa, informasi lanjutan tentang materi yang dibahas, dan penmabahan materi baru.

Kegiatan akhir (10 menit): 1) Salah satu siswa menyimpulkan hasil diskusi. 2) Peneliti sebagai fasilitator mempertegas kembali kesimpulan siswa dan mempertegas konsep-konsep yang didapat dari hasil diskusi. 3) Melakukan evaluasi.

Pertemuan ke-2. Pada pertemuan ke 2 ini pada prinsipnya langkah-langkah yang dilakukan sama seperti pertemuan ke 1, yaitu terdiri dari (a) Kegiatan awal (5 menit), (b) Kegiatan inti (30 menit), dan (c) Kegiatan akhir (5 menit)

Tahap Observasi/Evaluasi. Tahap observasi dilakukan bersamaan dengan tahap pemberian tindakan. Diamati adalah sikap siswa selama mengikuti pelajaran, mengrjakan LKS, maupun pada saat diskusi.

Tahap Rafleksi. Dengan menyimak berbagai hal pada siklus I akan didapatkan hasil apakah siklus I sudah mendapatkan hasil yang memuaskan atau belum. Untuk mendapatkan pencapaian yang lebih bagus, dilanjutkan pada siklus II, dengan perlakuan sesuai dengan hasil siklus I, dengan pemanfaatan media pembelajaran video materi pelajaran, dalam penelitian ini menggunakan video pelajaran bakteria. Disamping dilakukan peran guru untuk mengatur jalannya diskusi untuk lebih hidup lagi. 
Siklus II. Tahap Perencanaan: (a) Menelaah materi pelajaran serta membuat analisis materi pelajaran, satuan pelajaran dan rencana pembelajran. (b) Membuat lembar kerja siswa (LKS). (c) Membuat alat evaluasi. (d) Membuat lembar observasi. (e) Mempersiapkan alat-alat untuk melakukan percobaan atau eksperimen. Tahap Pelaksanaan: (a) Kegiatan Awal (10 menit): 1). Apersepsi dan memberikan motivasi kepada semua kelompok. 2) Mengecek alat dan bahan yang sudah disediakan. 3) Memberikan LKS serta permasalahan yang akan didiskusikan. (b) Kegiatan Inti (70 menit): 1) Semua kelompok mengerjakan LKS non eksperimen. 2) Peneliti berkeliling mengawasi tiap kelompok sambil meluruskan kalau ada hal-hal yang menyimpang serta sambil melakukan observasi. 3) Setelah setiap kelompok selesai mengerjakan LKS, peneliti menyuruh wakil tiap anggota kelompok untuk menempekan hasil karyanya di papan tulis/papan panel. 4) Setiap kelompok secara bergiliran mengamati hasil karya kelompok lainnya di depan papan panel. 5) Setelah semua kelompok selesai mengamati hasil karya kelompok lainnya, maka siswa kembali ke temapt duduknya, 6) Masing-masing kelompok berdiskusi di dalam kelompoknya untuk membuat pertanyaan kepada kelompok lainnya. 7) Dalam diskusi antar kelompok, salah satu anggota kelompok yang bertanya, diwajibkan menggunakan etika, menyebut nama kelompok dan nama anggota kelompok tersebut untuk menjawab atas pertanyaan yang disampaikan. 8) Kelompok yang ditanya kemudian melakukan diskusi dalam kelompok. Selanjutnya siswa yang ditunjuk tadi mewakili kelompoknya memberikan jawaban atas pertanyaan yang diberikan dan disertai dengan argumentasi-argumentasinya. 9) Setelah selesai diskusi antar kelompok, guru memberikan materi tambahan yang bersifat verivikatif atas jawaban yang diberikan siswa, informasi lanjutan tentang materi yang dibahas, dan penambahan materi baru. Dilakukan pemutaran video materi pelajaran tentang bakteria. (c) Kegiatan akhir (10 menit): 1) Siswa menyimpulkan hasil dari percobaan dan diskusi. 2) Peneliti mempertegas kembali kesimpulan siswa dan mempertegas konsep-konsep yang didapat dari hasil diskusi. 3) Melaksanakan evaluasi 
Tahap Observasi/Evaluasi. Tahap observasi dilakukan lagi bersamaan dengan tahap pemberian tindakan. Diamati adalah sikap siswa selama mengikuti pelajaran, mengerjakan LKS maupun pada saat diskusi. Tahap Rafleksi. Dengan menyimak berbagai hal pada siklus II akan didapatkan hasil apakah siklus II sudah mendapatkan hasil yang memuaskan atau belum. Dalam penelitian ini hanya dibatasi pada siklus II saja karena keterbatasan biaya, tenaga, dan waktu yang ada.

\section{HASIL DAN PEMBAHASAN}

Sebagaimana sudah disampaikan di depan dinyatakan bahwa sampel penelitian ini adalah kelas X Mia1 dengan jumlah siswa sebanyak 22 orang siswa. Dari sisi jumlah siswa dan luas ruangan yang ada, nampaknya dari sisi ruang untuk daya tampung sudah sesuai dengan disain pembelajaran yang ideal. Kondisi siswa yang terkait dengan pembelajaran biologi, nilai rata-rata ulangan akhir tahun ajaran 2017/2018 adalah 63,4. Ada beberapa hal yang perlu diperhatikan terkait dengan kondisi siswa yang dijadikan sampel yaitu:

Tabel 1. Deskripsi Kondisi Sampel

\begin{tabular}{|c|c|c|c|c|c|c|c|}
\hline \multirow{2}{*}{ No } & \multirow{2}{*}{ Uraian } & \multicolumn{2}{|c|}{$\begin{array}{l}\text { Aktivitas } \\
\text { Siswa }\end{array}$} & \multirow{2}{*}{ No } & \multirow{2}{*}{ Uraian } & \multicolumn{2}{|c|}{$\begin{array}{l}\text { Aktivitas } \\
\text { Siswa }\end{array}$} \\
\hline & & $\sum_{\text {Siswa }}^{\sum}$ & $\%$ & & & $\sum_{\text {Siswa }}^{\sum}$ & $\%$ \\
\hline 1 & Membawa buku & 22 & 100 & 7 & Belajar & 2 & 9,09 \\
\hline & $\begin{array}{l}\text { pelajaran IPA ke } \\
\text { sekolah }\end{array}$ & & & & $\begin{array}{l}\text { kelompok } \\
\text { rumah }\end{array}$ & & \\
\hline 2 & $\begin{array}{l}\text { Membuat catatan } \\
\text { penting/resume pada } \\
\text { buku catatannya } \\
\text { sebagai tanda siswa } \\
\text { telah membaca di } \\
\text { rumah }\end{array}$ & 15 & 68,18 & 8 & 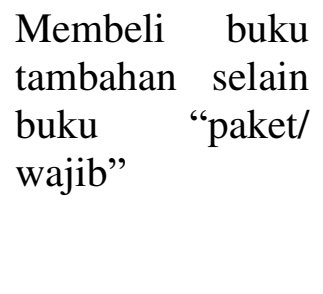 & 10 & 45,45 \\
\hline 3 & $\begin{array}{lr}\text { Memperhatikan } & \text { guru } \\
\text { pada } & \text { saat } \\
\text { menjelaskan } & \text { di } \\
\text { depan kelas } & \end{array}$ & 17 & 77,27 & 9 & $\begin{array}{l}\text { Membaca buku } \\
\text { di perpustakaan } \\
\text { yang terkait } \\
\text { dengan pelajaran } \\
\text { IPA yang telah } \\
\text { dijelaskan di } \\
\text { kelas }\end{array}$ & 2 & 9,09 \\
\hline 4 & $\begin{array}{lr}\text { Membuat } & \text { catatan } \\
\text { tambahan } & \text { dalam } \\
\text { buku catatan } & \text { untuk }\end{array}$ & 10 & 45,45 & 10 & $\begin{array}{l}\text { Berdiskusi } \\
\text { tentang pelajaran } \\
\text { IPA di sekolah }\end{array}$ & 2 & 9,09 \\
\hline
\end{tabular}




\begin{tabular}{lllll} 
melengkapi catatan & & pada saat jam \\
pang telah dibuat di & & & $\begin{array}{l}\text { kelaran } \\
\text { kosong }\end{array}$ & \\
rumah & & & & \\
& $\begin{array}{l}\text { Mengajukan } \\
\text { pertanyaan kepada } \\
\text { guru bila belum } \\
\text { mengerti atau tidak } \\
\text { jelas }\end{array}$ & & & \\
\hline
\end{tabular}

Dari Tabel 1 tampak bahwa ada 19,63\% atau 20\% menunjukkan kegiatan siswa yang mendukung aktivitas peningkatan hasil belajar. Hal ini berarti bahwa hanya $20 \%$ atau 4,4 atau 5 orang siswa yang aktivitasnya mengarah kepada kegiatan yang mendukung untuk meningkatkan hasil belajar siswa, sedangkan $80 \%$ atau 17 siswa yang aktivitasnya kurang mendukung untuk mengarah ke peneingkatan hasil belajar siswa. Aktivitas siswa yang sangat penting untuk mendapatkan perhatian dari sisi kegiatan siswa adalah jarang bertanya kepada guru, kurangnya kerja kelompok, tidak membaca atau tidak berkunjung ke perpustakaan, dan bila ada waktu luang, siswa kurang memanfaatkan waktu yang ada untuk berdiskusi dengan teman dalam bidang pelajaran.

Nilai awal yang diperoleh siswa sebelum diterapkannya pembelajaran dengan pendekatan tipe STAD berbais ergonomi, atau dengan kata lain pada saat pembelajaran awal ini menggunakan pendekatan konvensional yakni metode ceramah, dapat dilihat pada Tabel 2.

Tabel 2. Nilai Awal Siswa Kelas X Mia1 SMA Laboratorium Undiksha Singaraja Tahun Ajaran 2017/2018 Semester Ganjil

\begin{tabular}{|c|c|c|c|c|c|c|}
\hline $\mathrm{NO}$ & $\begin{array}{l}\text { NAMA } \\
\text { SISWA }\end{array}$ & & $\begin{array}{l}\text { NILAI } \\
\text { AWAL }\end{array}$ & NO & NAMA SISWA & $\begin{array}{l}\text { NILAI } \\
\text { AWAL }\end{array}$ \\
\hline 1 & Anna Sariri & & 50 & 13 & $\begin{array}{lll}\text { Made } & \text { Galu } & \text { Putra } \\
\text { Ardiana } & & \end{array}$ & 70 \\
\hline 2 & $\begin{array}{l}\text { Dewa Made } \\
\text { Wijaya }\end{array}$ & Satria & 68 & 14 & $\begin{array}{l}\text { Made Wulan Virgioni } \\
\text { Putri }\end{array}$ & 88 \\
\hline 3 & $\begin{array}{l}\text { Gede } \\
\text { Pramuditya }\end{array}$ & $\begin{array}{l}\text { Agus } \\
\text { Putra }\end{array}$ & 88 & 15 & Nk Nikita Putri Adnyani & 63 \\
\hline 4 & $\begin{array}{l}\text { Gede } \\
\text { Sayoga }\end{array}$ & Angga & 68 & 16 & $\begin{array}{l}\text { Ni Luh Chintya Sari } \\
\text { Sekar Wangi }\end{array}$ & 55 \\
\hline 5 & $\begin{array}{l}\text { Gede } \\
\text { Dwipayana }\end{array}$ & Krisna & 55 & 17 & Ni Luh Eka Suar Deni & 45 \\
\hline 6 & I Made & Arie & 73 & 18 & Ni Made Irene Kharisma & 55 \\
\hline
\end{tabular}




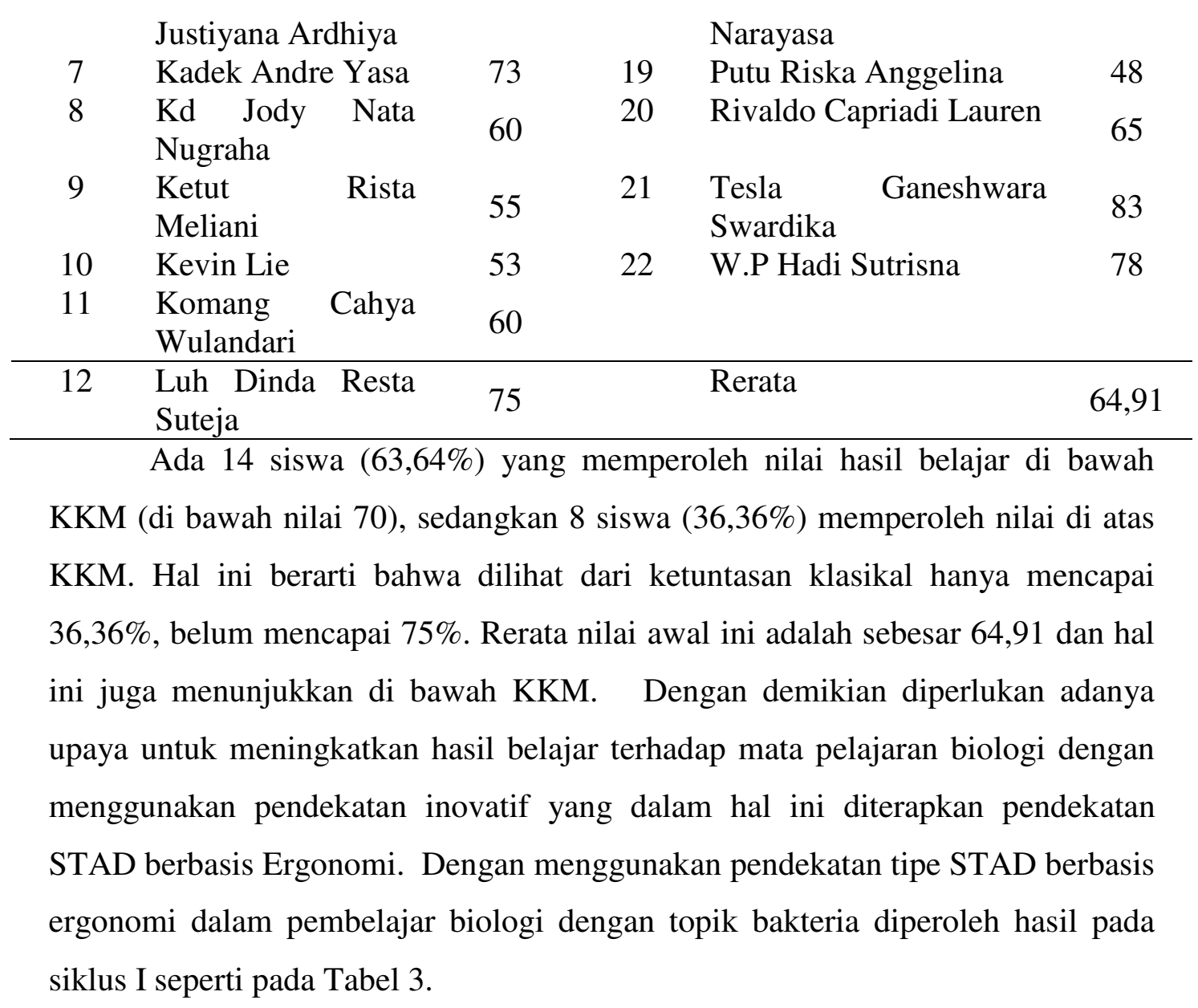

Tabel 3. Hasil Belajar Siswa pada Siklus I

\begin{tabular}{|c|c|c|c|c|c|c|c|c|c|}
\hline NO & $\begin{array}{l}\text { NAMA } \\
\text { SISWA }\end{array}$ & $\begin{array}{c}\text { TES } \\
1\end{array}$ & $\begin{array}{c}\text { TES } \\
2\end{array}$ & RERATA & $\mathrm{NO}$ & $\begin{array}{l}\text { NAMA } \\
\text { SISWA }\end{array}$ & $\begin{array}{c}\text { TES } \\
1\end{array}$ & $\begin{array}{c}\text { TES } \\
2\end{array}$ & RERATA \\
\hline 1 & Anna Sariri & 78 & 71 & 74.5 & 13 & $\begin{array}{l}\text { Made Galu } \\
\text { Putra } \\
\text { Ardiana }\end{array}$ & 70 & 73 & 71.5 \\
\hline 2 & $\begin{array}{l}\text { Dewa } \\
\text { Made } \\
\text { Satria } \\
\text { Wijaya }\end{array}$ & 75 & 73 & 74 & 14 & $\begin{array}{l}\text { Made } \\
\text { Wulan } \\
\text { Virgioni } \\
\text { Putri }\end{array}$ & 88 & 100 & 94 \\
\hline 3 & $\begin{array}{l}\text { Gede Agus } \\
\text { Pramuditya } \\
\text { Putra }\end{array}$ & 78 & 71 & 74.5 & 15 & $\begin{array}{l}\text { Nk Nikita } \\
\text { Putri } \\
\text { Adnyani }\end{array}$ & 68 & 70 & 69 \\
\hline 4 & $\begin{array}{l}\text { Gede } \\
\text { Angga } \\
\text { Sayoga }\end{array}$ & 75 & 73 & 74 & 16 & $\begin{array}{l}\text { Ni Luh } \\
\text { Chintya Sari } \\
\text { Sekar } \\
\text { Wangi }\end{array}$ & 79 & 92 & 85.5 \\
\hline 5 & $\begin{array}{l}\text { Gede } \\
\text { Krisna } \\
\text { Dwipayana }\end{array}$ & 65 & 70 & 67.5 & 17 & $\begin{array}{l}\text { Ni Luh Eka } \\
\text { Suar Deni }\end{array}$ & 63 & 67 & 65 \\
\hline
\end{tabular}


Jurnal IKA Vol. 17, No. 1 Maret 2019

ISSN 1829-5282

\begin{tabular}{|c|c|c|c|c|c|c|c|c|c|}
\hline 6 & $\begin{array}{l}\text { I Made } \\
\text { Arie } \\
\text { Justiyana } \\
\text { Ardhiya }\end{array}$ & 67 & 72 & 69.5 & 18 & $\begin{array}{l}\text { Ni Made } \\
\text { Irene } \\
\text { Kharisma } \\
\text { Narayasa }\end{array}$ & 79 & 72 & 75.5 \\
\hline 7 & $\begin{array}{l}\text { Kadek } \\
\text { Andre } \\
\text { Yasa }\end{array}$ & 85 & 73 & 79 & 19 & $\begin{array}{l}\text { Putu Riska } \\
\text { Anggelina }\end{array}$ & 62 & 73 & 67.5 \\
\hline 8 & $\begin{array}{l}\text { Kd Jody } \\
\text { Nata } \\
\text { Nugraha } \\
\end{array}$ & 64 & 70 & 67 & 20 & $\begin{array}{l}\text { Rivaldo } \\
\text { Capriadi } \\
\text { Lauren } \\
\end{array}$ & 73 & 82 & 77.5 \\
\hline 9 & $\begin{array}{l}\text { Ketut Rista } \\
\text { Meliani }\end{array}$ & 78 & 71 & 74.5 & 21 & $\begin{array}{l}\text { Tesla } \\
\text { Ganeshwara } \\
\text { Swardika }\end{array}$ & 70 & 73 & 71.5 \\
\hline 10 & Kevin Lie & 60 & 73 & 66.5 & 22 & $\begin{array}{l}\text { W.P Hadi } \\
\text { Sutrisna }\end{array}$ & 75 & 92 & 83.5 \\
\hline 11 & $\begin{array}{l}\text { Komang } \\
\text { Cahya } \\
\text { Wulandari }\end{array}$ & 67 & 71 & 69 & & & & & \\
\hline 12 & $\begin{array}{l}\text { Luh Dinda } \\
\text { Resta } \\
\text { Suteja }\end{array}$ & 73 & 73 & 73 & & Rerata & & & 73.79 \\
\hline
\end{tabular}

Berdasarkan Tabel 3 tampak bahwa ada 8 siswa (36,36\%) yang nilainya belum mencapai KKM, sedangkan 14 siswa $(63,64 \%)$ telah mencapai KKM. Nilai rerata pada siklus I adalah 73,79. Hal ini berarti ada kemajuan yang cukup meyakinkan dengan penerapan pendekatan STAD berbasis ergonomi untuk meningkatkan hasil belajar dalam pembelajaran Biologi di kelas X Mia 1 SMA Laboratorium Undiksha Singaraja. Walaupun demikian belum mencapai ketuntasan klasikal, di mana daya capai ketuntasan klasikalnya adalah 63,64\%, sedangkan ketuntasan klasikal yang ditarget adalah 75\%. Untuk melihat kemajuan hasil belajar siswa disajikan pada Tabel 4 .

Tabel 4. Perbandingan antara Nilai Awal dengan Rerata Siklus I dan Rerata Siklus I dengan Rerata Siklus II

\begin{tabular}{|c|c|c|c|c|c|c|c|c|}
\hline No & $\begin{array}{l}\text { Nilai } \\
\text { Awal } \\
\text { (NA) }\end{array}$ & $\begin{array}{l}\text { Rerata- } \\
\text { Siklus } \\
\text { 1(R1) }\end{array}$ & $\begin{array}{c}\text { Selisih NA } \\
\text { dan R1 }\end{array}$ & Keterangan & $\begin{array}{l}\text { Rerata- } \\
\text { Siklus } 1 \\
\quad(\mathrm{R} 1)\end{array}$ & $\begin{array}{l}\text { Rerata } \\
\text { Siklus } \\
2 \text { (R2) }\end{array}$ & $\begin{array}{l}\text { Selisih } \\
\text { R1 } \\
\text { dan } \\
\text { R2 }\end{array}$ & Keterangan \\
\hline 1 & 50 & 74.5 & 24.5 & naik & 74.5 & 81.5 & 7 & naik \\
\hline 2 & 68 & 74 & 6 & naik & 74 & 79 & 5 & naik \\
\hline 3 & 88 & 74.5 & -13.5 & turun & 74.5 & 82.5 & 8 & naik \\
\hline
\end{tabular}




\begin{tabular}{ccccccccc}
4 & 68 & 74 & 6 & naik & 74 & 85.5 & 11.5 & naik \\
5 & 55 & 67.5 & 12.5 & naik & 67.5 & 78.5 & 11 & naik \\
6 & 73 & 69.5 & -3.5 & turun & 69.5 & 79 & 9.5 & naik \\
7 & 73 & 79 & 6 & naik & 79 & 82.5 & 3.5 & naik \\
8 & 60 & 67 & 7 & naik & 67 & 79 & 12 & naik \\
9 & 55 & 74.5 & 19.5 & naik & 74.5 & 74.5 & 0 & tetap \\
10 & 53 & 66.5 & 13.5 & naik & 66.5 & 89.5 & 23 & naik \\
11 & 60 & 69 & 9 & naik & 69 & 81.5 & 12.5 & naik \\
12 & 75 & 73 & -2 & turun & 73 & 75 & 2 & naik \\
13 & 70 & 71.5 & 1.5 & naik & 71.5 & 75 & 3.5 & naik \\
14 & 88 & 94 & 6 & naik & 94 & 81.5 & -12.5 & turun \\
15 & 63 & 69 & 6 & naik & 69 & 75 & 6 & naik \\
16 & 55 & 85.5 & 30.5 & naik & 85.5 & 82.5 & -3 & turun \\
17 & 45 & 65 & 20 & naik & 65 & 69.5 & 4.5 & naik \\
18 & 55 & 75.5 & 20.5 & naik & 75.5 & 82.5 & 7 & naik \\
19 & 48 & 67.5 & 19.5 & naik & 67.5 & 69 & 1.5 & naik \\
20 & 65 & 77.5 & 12.5 & naik & 77.5 & 78.5 & 1 & naik \\
21 & 83 & 71.5 & -11.5 & turun & 71.5 & 86.5 & 15 & naik \\
22 & 78 & 83.5 & 5.5 & naik & 83.5 & 78 & -5.5 & turun \\
\hline
\end{tabular}

Dari Tabel 4 tampak bahwa selisih antara nilai awal dengan rerata pada siklus I, ada sejumlah siswa yang nilainya mengalami kenaikan yaitu 17 orang siswa $(77,27 \%)$, sedangkan yang mengalami penurunan nilai ada sebanyak 5 orang siswa. (22,73\%). Dari hasil tersebut dapat dirafleksikan bahwa kegiatan belajar mengajar pada siklus I masih perlu ditingkat ke siklus II dengan memperhatikan beberapa kelemahan yang ada pada saat pelaksanaan kegiatan belajar mengajar pada siklus I yaitu: (1) perhatian siswa masih belum terpusat pada model pembelajaran yang digunakan, (2) pada saat diskusi antar kelompok, belum semua anggota dalam kelompok ikut terlibat di dalamnya, artinya masih ada satu atau beberapa siswa yang mendominasi, dan (4) media pembelajaran yang digunakan belum menjadi daya tarik untuk memusatkan perhatian siswa dalam pembelajaran. Untuk memperbaiki kelemahan pada siklus I pada siklus II dirancang tambahan aktivitas yaitu penggunaan video pembelajaran seperti video reproduksi bakteri secara konyugasi, transduksi, dan transformasi. Untuk menghindari dominasi salah satu atau beberapa siswa, maka dalam pengaturan diskusi, peran guru lebih diintensifkan. Hasil pada siklus II disajikan pada Tabel 5 . 
Tabel 5. Hasil Evaluasi pada Siklus II

\begin{tabular}{|c|c|c|c|c|c|c|c|c|c|}
\hline \multirow[t]{2}{*}{ No } & \multirow[t]{2}{*}{ Nama } & \multicolumn{2}{|c|}{ Siklus 2} & \multirow{2}{*}{$\begin{array}{l}\text { Rata- } \\
\text { Rata }\end{array}$} & \multirow[t]{2}{*}{ No } & \multirow[t]{2}{*}{ Nama } & \multicolumn{2}{|c|}{$\begin{array}{l}\text { Siklus } \\
2\end{array}$} & \multirow[t]{2}{*}{ Rata-Rata } \\
\hline & & $\mathrm{T} 1$ & $\mathrm{~T} 2$ & & & & $\mathrm{~T} 1$ & $\mathrm{~T} 2$ & \\
\hline 1 & Anna Sariri & 89 & 74 & 81.5 & 12 & $\begin{array}{l}\text { Luh Dinda } \\
\text { Resta Suteja }\end{array}$ & 74 & 76 & 75 \\
\hline 2 & $\begin{array}{l}\text { Dewa Made } \\
\text { Satria Wijaya }\end{array}$ & 74 & 84 & 79 & 13 & $\begin{array}{l}\text { Made Galu } \\
\text { Putra } \\
\text { Ardiana }\end{array}$ & 74 & 76 & 75 \\
\hline 3 & $\begin{array}{l}\text { Gede Agus } \\
\text { Pramuditya Putra }\end{array}$ & 75 & 90 & 82.5 & 14 & $\begin{array}{l}\text { Made } \\
\text { Wulan } \\
\text { Virgioni } \\
\text { Putri }\end{array}$ & 89 & 74 & 81.5 \\
\hline 4 & $\begin{array}{l}\text { Gede Angga } \\
\text { Sayoga }\end{array}$ & 89 & 82 & 85.5 & 15 & $\begin{array}{l}\text { Nk Nikita } \\
\text { Putri } \\
\text { Adnyani } \\
\text { Ni Luh }\end{array}$ & 74 & 76 & 75 \\
\hline 5 & $\begin{array}{l}\text { Gede Krisna } \\
\text { Dwipayana }\end{array}$ & 75 & 82 & 78.5 & 16 & $\begin{array}{l}\text { Chintya Sari } \\
\text { Sekar } \\
\text { Wangi }\end{array}$ & 75 & 90 & 82.5 \\
\hline 6 & $\begin{array}{l}\text { I Made Arie } \\
\text { Justiyana Ardhiya }\end{array}$ & 74 & 84 & 79 & 17 & $\begin{array}{l}\text { Ni Luh Eka } \\
\text { Suar Deni } \\
\text { Ni Made }\end{array}$ & 68 & 71 & 69.5 \\
\hline 7 & $\begin{array}{l}\text { Kadek Andre } \\
\text { Yasa }\end{array}$ & 75 & 90 & 82.5 & 18 & $\begin{array}{l}\text { Irene } \\
\text { Kharisma } \\
\text { Narayasa }\end{array}$ & 75 & 90 & 82.5 \\
\hline 8 & $\begin{array}{l}\text { Kd Jody Nata } \\
\text { Nugraha }\end{array}$ & 74 & 84 & 79 & 19 & $\begin{array}{l}\text { Putu Riska } \\
\text { Anggelina }\end{array}$ & 60 & 78 & 69 \\
\hline 9 & $\begin{array}{l}\text { Ketut Rista } \\
\text { Meliani }\end{array}$ & 73 & 76 & 74.5 & 20 & $\begin{array}{l}\text { Rivaldo } \\
\text { Capriadi } \\
\text { Lauren } \\
\text { Tesla }\end{array}$ & 75 & 82 & 78.5 \\
\hline 10 & Kevin Lie & 89 & 90 & 89.5 & 21 & $\begin{array}{l}\text { Ganeshwara } \\
\text { Swardika }\end{array}$ & 89 & 84 & 86.5 \\
\hline 11 & $\begin{array}{l}\text { Komang Cahya } \\
\text { Wulandari }\end{array}$ & 89 & 74 & 81.5 & 22 & $\begin{array}{l}\text { W.P Hadi } \\
\text { Sutrisna }\end{array}$ & 74 & 82 & 78 \\
\hline
\end{tabular}

Berdasarkan Tabel 5, ada 2 siswa $(9,09 \%)$ yang masih nilainya belum mencapai KKM, sedangkan 20 siswa $(90,91 \%)$ telah mencapai KKM. Rerata nilai kelasnya sudah melebihi KKM yaitu sebesar 79,36. Hal ini berarti ada kemajuan yang sangat meyakinkan dalam penerapan pendekatan STAD berbasis ergonomi dengan media pembelajaran video materi pelajaran untuk meningkatkan hasil 
belajar siswa dalam pembelajaran Biologi di kelas X Mia1 SMA Laboratorium Undiksha Singaraja pada topik bakteria. Ketuntasan klasikal atau daya capai ketuntasan klasikalnya adalah sebeesar 90,91\%, sedangkan ketuntasan klasikal yang ditarget adalah 75\%. Kemajuan dari siklus I ke siklus II ada 4 (18,18\%) siswa yang nilainya turun atau tetap. Dari hasil niai yang diperoleh dalam siklus II ini secara umum dapat dinyatakan bahwa dengan penerapan pendekatan pembelajaran tipe STAD berbasis ergonomi dapat meningkatkan nilai pelajaran yang diperoleh siswa.

Dalam penelitian tindakan kelas ini telah berhasil digunakan untuk meningkatkan hasil beljar siswa. Beberapa factor yang dapat digunakan untuk menjeaskan hal ini adalah: Dalam pembelajaran dengan menggunakan STAD berbasis ergonomi ini hasil observasi menunjukkan bahwa adanya kerjasama dalam kelompok yang lebih aktif dan efektif dalam memecahkan masalah yang ada, baik pada saat kelompok siswa itu mengerjakan LKS maupun pada saat terjadi diskusi antar kelompok. Dalam diskusi antar kelompok di mana salah satu kelompok akan menanyakan hasil kerja dari LKS yang telah mereka kerjakan dan dicermati oleh kelompok lain di papan display, maka kelompok yang ditanya itu terlebih dahulu mendiskusikannya dengan siswa lainnya dalam kelompok tersebut. Hal ini sebagai indikator bahwa di antara mereka terjadi kerja yang partisipatif dan bukan kerja individual.

Dalam proses pembelajaran dengan menerapkan tipe STAD berbasis ergonomi terjadi kemampuan dalam menganalisis dan mensintesis terhadap informasi yang disampaikan oleh guru. Setiap siswa terlibat aktif baik jasmani maupun mental pada setiap aspek kegiatan sehingga pemahaman siswa terhadap materi pelajaran menjadi lebih baik. Hal ini senada dengan pendapat yang disampaikan oleh Slavin (1995), Arnyana (2006), dan Warpala (2006) yang menyatakan bahwa dalam pembelajaran dengan menggunakan pendekatan kooperatif terjadi peningkatan kemampuan dalam melakukan analisis dan sintesis terhadap segala informasi sehingga penguasaan materi pelajaran menjadi lebih meningkat. 
Untuk mengurangi rasa kebosanan dan rasa lelah dan keluhan yang terjadi pada otot rangka karena duduk yang cukup lama, maka siswa diajak secara aktif melakukan istirahat pendek dalam waktu 5-7 menit dengan melakukan peregangan dan ditambah lagi dengan cara mencermati hasil kerja kelompok lainnya yang terpasang di papan display. Cara ini bertujuan untuk mengurangi rasa lelah, kebosanan dan keluhan muskuloskeletal (Manuaba, 2006a; 2002), serta membandingkan hasil kerja mereka pada saat mengerjakan LKS dengan hasil kerja kelompok lainnya. Dengan menjadikan suasana belajar yang nyaman, aman dan sehat serta kondusif merupakan salah satu komponen yang dapat digunakan untuk meningkatkan motivasi belajar siswa. Dengan adanya peningkatan motivasi belajar ini, maka muara akhir dari kondisi yang demikian adalah terjadinya peningkatan prestasi belajar siswa.

Kebosanan dalam proses pembelajaran ditandai dengan berkurangnya perhatian siswa terhadap materi yang sedang dibahas atau siswa mengalami kesulitan dalam mempertahankan perhatiannya pada tugas yang sedang dilaksanakannya. Dalam hal ini Grandjean (1988), Manuaba (2006b) menjelaskan bahwa kebosanan bisa terjadi disebabkan oleh stimulasi yang rendah, tuntutan fisik dan mental yang rendah yang mengakibatkan stimulus yang kecil pada daerah kesadaran di otak. Konsekuensinya sistem limbik akan terpengaruh pada reaksi dari organisme secara keseluruhan akan menurun.

Dalam penelitian pembelajaran dengan menggunakan Pendekatan Ergonomi (PE) yang diberlakukan pada kelompok kontrol ternyata memunculkan rasa bosan sebesar 18,73 (26,40\%) lebih tinggi dibandingkan dengan kelompok eksperimen yang menggunakan proses pembelajaran melalui PE. Hasil uji beda menunjukkan bahwa rerata skor kebosanan pada kelompok kontrol berbeda bermakna dengan rerata skor kebosanan pada kelompok eksperimen $(p<0,05)$ (Wijana, 2008).

\section{SIMPULAN DAN SARAN}

Dari hasil penelitian ini dapat disimpulkan bahwa: (1) Penerapan model pembelajaran kooperatif tipe STAD berbasis ergonomi dapat meningkatkan hasil 
belajar siswa kelas X Mial SMA LAB Undiksha. (2) Pada siklus I ada 8 $(36,36 \%)$ siswa yang nilainya belum mencapai KKM, sedangkan $14(63,64 \%)$ siswa telah mencapai KKM. Nilai rerata pada siklus I adalah 73,79. Ketuntasan klasikalnya baru mencapai 63,64\% dari 75\% yang ditarget. Pada siklus II ada 2 $(9,09 \%)$ siswa yang masih nilainya belum mencapai KKM, sedangkan 20 $(90,91 \%)$ siswa telah mencapai KKM. Rerata nilai kelasnya sudah melebihi KKM yaitu sebesar 79,36. Ketuntasan klasikalnya adalah sebesar 90,91\%, dari ketuntasan klasikal yang ditarget sebesar 75\%. Dari simpulan di atas, selanjutnya saran yang dapat disampaikan adalah: (1) Dalam pembelajaran biologi dengan topik mahluk hidup mirip Protista khususnya mikroorganisme bakteria dan virus dapat digunakan atau diterapkannya model pembelajaran kooperatif tipe STAD berbasis ergonomic. (2) Kelengkapan media pembelajaran yang dapat menunjang keberhasilan model pembelajaran ini adalah dengan mengunakan media video sesuai dengan materi yang dibahas;

\section{DAFTAR PUSTAKA}

Anonimus. 2017. Buku Pelajaran Biologi SMA Semester Ganjil. Jakarta: Kementerian Pendidikan dan Kebudayaan Republik Indonesia.

Arends, R.I. 2004. Learning to Teach. New York : McGraw-Hill.

Arnyana, IBP. 2006. Pengaruh Penerapan Strategi Pembelajaran Inovatif pada Pelajaran Biologi terhadap Kemampauan Berpikir Kreatif Siswa SMA. Jurnal Pendidikan dan Pengajaran IKIP Negeri Singaraja No 3 Tahun xxxix Juli 2006 : 45-51

Grandjean, E. 1988Fitting the Task to the Man.London : Taylor \& Farncis.

Manuaba, A. 2002. Total Approach is Amust to Small and Medium scale Enterprises to Attain Sustainable Improvement. Dalam Proceeding National Industrial Egineering Conference; Industrial Engineering in Competitive and BorderlessWorld: Innovation and Sustainable Development in The Industries. Surabaya 20-23 Februari 2002.

Manuaba, A. 2003. Organisasi Kerja, Ergonomi dan Produktivitas. Makalah disampaikan dalam seminar nasional ergonomi, di Hotel Peninsula Jakarta tanggal 9-10 April 2003. 
Manuaba, A. 2006a. Total Approach in Evaluating Comfort Work Place. Makalah disampaikan pada simposium 25 th UOEH International Symposium on Confort at The Work Place Kitakyushu, Japan 23-25 Oct 2006.

Manuaba, A. 2006b. Total Approach in Evaluating Comfort Work Place. Makalah disampaikan pada simposium 25 th UOEH International Symposium on Confort at The Work Place Kitakyushu, Japan 23-25 Oct 2006.

Slavin, R. E. 1995. Cooperative Learning. London : Allyn and Bacon.

Warpala, S. I W. 2006. Pengaruh Pendekatan Pembelajaran dan Strategi Belajar Koopertatif Terhadap Pemahaman dan Keterampilan Berpikir Kritis dalam Pembelajaran IPA SD. (Disertasi). PSSJ. Teknologi Pembelajaran. Program Pascasarjana Universitas Negeri Malang. Tidak Diterbitkan.

Wijana, Nyoman. 2008. Pembelajaran Sains Melalui Pendekatan Ergonomi Mengurangi Keluhan Muskuloskeletal, Kebosanan Dan Kelelahan Serta Meningkatkan Motivasi Dan Prestasi Belajar Siswa SD 1 Sangsit Kecamatan Sawan Kabupaten Buleleng. Disertasi. Tidak Diterbitkan. 